ISSN: 2224-0616

Int. J . Agril. Res. Innov. \& Tech. 6(2): 5-11, December, $2016 \quad$ Available online at http://www.ijarit.webs.com

\title{
SOCIO-ECONOMIC IMPACTS OF Parthenium hysterophorus L. IN EAST SHEWA AND WEST ARSI ZONES OF ETHIOPIA
}

\author{
Niguse Hundessa $^{1}$ and Kifle Belachew ${ }^{2 *}$
}

Received 19 July 2016, Revised 21 November 2016, Accepted 27 December 2016, Published online 31 December 2016

\begin{abstract}
Parthenium hysterophorus L. is non-native invasive plant species belongs to the family Asteraceae. Currently it is a notorious weed in Ethiopia. Socio-economic impacts as well as the local people's perception towards P. hysterophorus are poorly understood. Thus, the aim of this study was to generate information for a better understanding of the means of dispersal, source introduction and socio-economic impacts, of P. hysterophorus in East shewa and West arsi Zones of the Oromia Regional State of Ethiopia. The study revealed that parthenium was introduced mainly by following vehicles road and railways. This weed grows throughout the year. This results in its fast dispersal. Many mechanisms were assumed by respondents for fast distribution of $\mathrm{P}$. hysterophorus in the study zones. Among these vehicles and wind are the major agents, which proliferate the seeds of the weed. Based on the study it grows in roadsides, grazing land, cropland, village sides and wastelands. Most of respondents also indicated that the weed first appeared on roadside and propagated to other habitats. This finding indicated that the weed high in disturbed habitats. Control methods, which are mostly practiced by local people, were tillage and hand weeding. However, these methods were not an efficient to control the weed distribution; rather it is expanding from time to time since its invasions. P. hysterophorus has a number of socioeconomic impacts that include effect on crop and livestock production, human health, soil fertility and biodiversity. This finding showed that it competes and suppress the growth of crops due its allelopathic nature. Seeds of this weed changes the normal flavor of food when mix with it. It also colonized grazing fields, thus causing animal food scarcity, animals' health defect. This finding also reported that P. hysterophorus has health hazards on human being, which include allergic, skin itching (irritation), cough and hemorrhage. Generally, P. hysterophorus is a foremost troublesome weed and subterfuge threat on agriculture, biodiversity and on human health. Therefore, proper and targeted control methods should be employed to control the further spread and reduce the adverse impacts.
\end{abstract}

Keywords: Parthenium hysterophorus, Socio-Economic Impact, Health Impact, Allelopatic Effect

${ }^{1}$ Ethiopia Institute of Agricultural Research, Wondogenet Agricultural Research center, P.O.Box 198, Shashemane, Ethiopia

${ }^{2}$ Ethiopia Institute of Agricultural Research, Jimma Agricultural Research Center, P.O.Box 192, Jimma, Ethiopia

*Corresponding author's email: kiflekef@ gmail.com (Kifle Belachew)

\section{Introduction}

Parthenium hysterophorus belongs to the family Asteraceae, an extremely diverse family with a cosmopolitan distribution. It has been further classified under the tribe Heliantheae and subtribe Ambrosiinae. It is described as an annual, procumbent, diffused leafy herb with a height of $0.5-1.50 \mathrm{~m}$, reaching a maximum of 2 $\mathrm{m}$ in good soils (Parsons and Cuthbertson, 1992).

P. hysterophorus was regarded to be introduced accidentally through aid shipments or from Somalia during Ethio-Somali war in 1976/77 (Besufekad et al., 2005; Taye, 2002). Its invasion expanded at alarming rate in all directions mainly following slope gradient and colonizing substantial areas in Ethiopia (Belachew and Tessema, 2015; Niguse et al., 2016). Even though, there are different factors that favor fast distribution of the weed, flooding and movement of vehicles are the major factors. This radiation occurs particularly in the direction of low slope and waterways (Adane, 2008).

P. hysterophorus clearly poses a major threat to rangelands, croplands and cause health problems of animals and human despite its management was suggested with different scholars (Kifle et al., 2011). Overall impact on crop production system is multifaceted, both direct and indirect by affecting grazing land, animal health, milk and meat quality, and marketing of pasture seeds and grain. The main impact of parthenium on crops relates to its allelopathic properties. The chemicals significantly inhibit the germination 
and subsequent growth of a range of crop plants (Navie et al., 1996; Evans, 1997). Jayachandra (1971) stated that the parthenium can be a serious problem in grasslands and can reduce the pasture carrying capacity by up to $90 \%$. It is also known to cause human health problems like asthma, bronchitis, dermatitis, and hay fever (Kololgi et al., 1997; Srirama Rao et al., 1991). Evans (1997) and Towers and Subba Rao (1992) also reported that close contact with P. hysterophorus could cause allergic contact dermatitis while inhalation of pollen can cause allergic rhinitis, which can develop into bronchitis or asthma in susceptible humans. Even though parthenium is causing severe damage, on crop production, animal husbandry, and biodiversity in Ethiopia, there is no adequate information is available with regard to impact of P. hysterophorus in East Shewa and West Arsi. Thus this study initiated with the objectives of to assess community perception on means and source of introduction, dispersal, habitats infested and practices to control $P$. hysterophorus in the study area and to assess the socio-economic impacts of $\mathrm{P}$. hysterophorus in study area.

\section{Materials and Methods}

To congregate information about socio-economic impacts as well as the local people's perception towards the parthenium in the study area, data were collected through semi-structured questionnaires. The questionnaires were provided to farmers, development agents (DAs), experts in the different levels of Minster of agriculture who were involved in addressing the impact of parthenium.

Depending on the severity of the invasion and distribution of parthenium in the Zones, respondents in the districts were stratified into highly invaded, medium invaded and noninfested areas based on preliminary survey and group discussion conducted with the zonal agricultural experts to investigate the economic impacts of parthenium under varying infestation.
This approach allowed comparison of results from infested areas with areas not yet infested. The latter areas served as a 'control' and without control communities, it would be difficult to determine the effect of the invasive species on the target group (Wittenberg, 2004). A total of 183 respondents among households, DA's and experts were selected using systematic sampling technique.

\section{General characteristics of respondents}

The respondents have different occupation and source of income. Of all respondents, 56\% are farmers, $27 \%$ pastoralist, $14 \%$ development agent and 3\% are experts. The age of the overall sample, respondents ranged from 20 to 70 . Age is important to estimate year at which parthenium introduced and to compare the problems and impacts before and after introduction.

Of all the total respondents, $77 \%$ were able to read and write and they attended formal education from elementary to university. About $56 \%$ of all the respondents had attended elementary education, $16 \%$ of all the sample farmers had attended second cycle elementary education, $6 \%$ of the overall sample respondents had completed high school education and 16\% had received diploma and above. Education is crucial to understand the newly emerging problems and their impacts. This is in line with Senayit et al. (2004) which state that education is one of the most important factors that affect the dissemination and adoption of new technologies. Several studies indicate that farmers who attended some level of formal schooling are more likely to adopt new technologies. The fact that a large proportion of the sample farmers in this study are able to read and write, provides a good opportunity to design appropriate technology dissemination and utilization strategies. Both men and women were interviewed with women accounting for $24 \%$ of the total sample size.

Table 1. Occupation and education level of respondents in East Shewa and West Arsi Zones, ONRGS.

\begin{tabular}{lccccc}
\hline \multicolumn{1}{c}{ Occupation } & Frequency & Percent & Education level & Frequency & Percent \\
\hline Farmer & 103 & 56 & Illiterate & 42 & 23 \\
Pastoralist & 49 & 27 & Elementary & 102 & 56 \\
DAs & 26 & 14 & High school & 10 & 5 \\
Expert & 5 & 3 & 10+3 and above & 29 & 16 \\
\hline Total & 183 & 100 & Total & 183 & 100 \\
\hline
\end{tabular}

Techniques of data analysis

The questionnaires were coded and the data entered in Computer for analysis. The socioeconomic data were analysed by using SPSS Version 16.0 software.

\section{Results and Discussion}

Respondents' perception on P.
hysterophorus means and source of
introduction, dispersal, habitats infested
and practices to control


Most of respondents in the study area knew the impacts, source of introduction and means of dispersal of parthenium. In high infestation category, all respondents became aware about the weed. However, despite their awareness the rate of infestation increasing from time to time, this may be because of improper action was not done by different stakeholders. In addition, the communities were not mobilized to take action on the weed.

\section{Respondents' perception on means and source of introduction}

This finding also indicated that $88 \%, 63 \%$ and $43 \%$ of respondents in high, medium and noninfestation category were perceived that parthenium was introduced by following vehicles road and rail ways. It also introduced by wind, animal, water and human as indicated in table (Table 2). According to many authors P. hysterophorus was introduced to certain area by different means.

Table 2. Respondent perception on means of introduction of parthenium into East Shewa and West Arsi zones, Ethiopia.

\begin{tabular}{lcccccccc}
\hline Means of introduction & $\begin{array}{c}\text { High } \\
\text { infestation } \\
\mathrm{N}=60\end{array}$ & \multicolumn{2}{c}{$\begin{array}{c}\text { Medium } \\
\text { infestation } \\
\mathrm{N}=60\end{array}$} & $\begin{array}{c}\text { No infestation } \\
\mathrm{N}=40\end{array}$ & \multicolumn{2}{c}{ Overall sample } \\
& $\mathrm{n}$ & $\%$ & $\mathrm{n}$ & $\%$ & $\mathrm{n}$ & $\%$ & $\mathrm{n}$ & $\%$ \\
\hline Vehicles & 53 & 88 & 38 & 63 & 17 & 43 & 108 & 68 \\
Wind & 33 & 55 & 27 & 45 & 17 & 43 & 77 & 48 \\
Water (flood) & 26 & 43 & 12 & 20 & 10 & 25 & 48 & 30 \\
Animal & 31 & 52 & 14 & 23 & 9 & 23 & 54 & 38 \\
Human & 14 & 23 & 2 & 3 & 1 & 3 & 17 & 11 \\
\hline
\end{tabular}

$\mathrm{N}=$ sample size of each category, $\mathrm{n}=$ Frequency

According to respondents in all categories, source of introduction of P. hysterophorus was foreign country (57\%) and Dire-dawa (23\%).Whereas, $16 \%$ of respondents believed that it came from nearby districts through different means (Table $3)$.

Respondents' perception on means and source of introduction is in line with the study of other scholars' speculation. Tamado et al. (2002) reported that in Ethiopia, it is believed to have been introduced in 1976/77 with army vehicles from Somalia and has become a serious weed both in arable and grazing lands. GISP (2004) also reported that parthenium weed was first seen in 1980s near food-aid distribution centers in Ethiopia. According to Taye et al. (2004) the presence of Puccinia abrupta on parthenium weed in Ethiopia might also explain indirectly the introduction of parthenium weed from neighbouring countries.

Table 3. Respondents' perception on source of introduction of P. hysterophorus in East Shewa and West Arsi Zones, Ethiopia.

\begin{tabular}{lcccccccc}
\hline $\begin{array}{l}\text { Source of } \\
\text { introduction }\end{array}$ & $\begin{array}{c}\text { High infestation } \\
\mathrm{N}=60\end{array}$ & $\begin{array}{c}\text { Medium } \\
\text { infestation } \\
\mathrm{N}=60\end{array}$ & $\begin{array}{c}\text { No infestation } \\
\mathrm{N}=40\end{array}$ & \multicolumn{2}{c}{$\begin{array}{c}\text { Total } \\
\mathrm{N}=160\end{array}$} \\
\hline & $\mathrm{n}$ & $\%$ & $\mathrm{n}$ & $\%$ & $\mathrm{n}$ & $\%$ & $\mathrm{n}$ & $\%$ \\
\hline Foreign & 43 & 72 & 31 & 52 & 17 & 43 & 91 & 57 \\
Dire-Dawa & 22 & 37 & 14 & 23 & 1 & 3 & 37 & 23 \\
Near Districts & 5 & 8 & 14 & 23 & 7 & 18 & 26 & 16 \\
I do not know & 1 & 2 & 5 & 8 & 16 & 40 & 22 & 14 \\
\hline
\end{tabular}

$\mathrm{N}=$ sample size of each category $\mathrm{n}=$ Frequency

\section{Respondents' perception on dispersal of P. hysterophorus}

According to $95 \%$ of respondents in high infestation category and $85 \%$ in medium infestation, P. hysterophorus grows through out of the year. Fifty-five of respondents in noninfestation category also believed that the weed grows all time in the year. This results in its fast dispersal. All respondents in high infestation category and $83 \%$ in medium infestation perceived that $\mathrm{P}$. hysterophorus is highly invasive.

Many mechanisms were assumed by respondents for fast distribution of $\mathrm{P}$. hysterophorus in the study zones. These dispersal mechanisms include vehicles (65\%), wind (55\%), flood (46\%), livestock (45\%), seeds (41\%) and construction materials (28\%). Among these vehicles and wind are the major agents, which proliferate $\mathrm{P}$. 
hysterophorus seeds (Table 4). These local dispersal of P. hysterophorus seeds occur mechanisms recognized by respondents agree locally by wind and water, while motor vehicles, with studies of other workers. Adane (2008) machinery and livestock movements, crop and stated that flooding and vehicle took the lead for pasture seeds contribute for long distance fast rate of distribution in to different Kebeles and districts. Auld et al. (1983) also stated that dispersal.

Table 4. Respondents perception on agents facilitate dispersal of P. hysterophorus in East Shewa and West Arsi Zones, Ethiopia.

\begin{tabular}{lcccccccc}
\hline $\begin{array}{l}\text { Agents facilitating } \\
\text { dispersal of Parthenium }\end{array}$ & $\begin{array}{c}\text { High infestation } \\
\mathrm{N}=60\end{array}$ & $\begin{array}{c}\text { Medium } \\
\text { infestation } \\
\mathrm{N}=60\end{array}$ & $\begin{array}{c}\text { No infestation } \\
\mathrm{N}=40\end{array}$ & \multicolumn{2}{c}{$\begin{array}{c}\text { Total } \\
\mathrm{N}=160\end{array}$} \\
\hline & $\mathrm{n}$ & $\%$ & $\mathrm{n}$ & $\%$ & $\mathrm{n}$ & $\%$ & $\mathrm{n}$ & $\%$ \\
\hline Vehicles & 54 & 90 & 39 & 65 & 11 & 28 & 104 & 65 \\
Wind & 38 & 63 & 39 & 65 & 11 & 28 & 88 & 55 \\
Livestock Leg & 36 & 60 & 32 & 53 & 4 & 10 & 72 & 45 \\
Water & 24 & 40 & 42 & 70 & 8 & 20 & 74 & 46 \\
Seeds & 30 & 50 & 26 & 43 & 9 & 23 & 65 & 41 \\
Construction materials & 21 & 35 & 23 & 38 & 0 & 0 & 44 & 28 \\
\hline
\end{tabular}

$\mathrm{N}=$ sample size of each category, $\mathrm{n}=$ Frequency

\section{Respondents' perception on habitats infested}

According to the respondents in high infestation category roadside (98\%), pastoral (97\%), village (95\%), crop land (92\%) and waste land (67\%) were the highly infested habitats, while respondents in no infestation category observed parthenium on roadside (25\%), pastoral $(25 \%)$, village $(24 \%)$, crop land (25\%) and wasteland (20\%) in nearby districts (Table 5). Most of respondents also indicated that the weed first appeared on roadside and propagated to other habitats. This finding indicated that the weed was very high in disturbed habitat. This is in line with Taye (2002) who stated that parthenium weed population was high in places where the soils are disturbed constantly for purposes of construction of road, buildings, and waterways for irrigation channels. Therefore, the extensive density along roadsides might be due to the routine disturbance and grading of road verges and transportation of sands and gravels from parthenium weed infested to non-infested areas.

Table 5. The infested habitats with P. hysterophorus in East Shewa and West Arsi Zones.

\begin{tabular}{lcccccccc}
\hline Infested habitats & $\begin{array}{c}\text { High infestation } \\
\mathrm{N}=60\end{array}$ & \multicolumn{2}{c}{$\begin{array}{c}\text { Medium } \\
\text { infestation } \\
\mathrm{N}=60\end{array}$} & \multicolumn{2}{c}{$\begin{array}{c}\text { No infestation } \\
\mathrm{N}=40\end{array}$} & \multicolumn{2}{c}{$\begin{array}{c}\text { Total } \\
\mathrm{N}=160\end{array}$} \\
\cline { 2 - 9 } & $\mathrm{n}$ & $\%$ & $\mathrm{n}$ & $\%$ & $\mathrm{n}$ & $\%$ & $\mathrm{n}$ & $\%$ \\
\hline Road side & 59 & 98 & 57 & 95 & 10 & 25 & 126 & 79 \\
Pastoral & 58 & 97 & 28 & 47 & 10 & 25 & 96 & 60 \\
Village & 57 & 95 & 57 & 95 & 9 & 24 & 123 & 77 \\
Cropland & 55 & 92 & 50 & 83 & 10 & 25 & 115 & 72 \\
Wasteland & 40 & 67 & 35 & 58 & 8 & 20 & 83 & 52 \\
\hline
\end{tabular}

Respondents' practices to control $\mathbf{P}$. hy sterophorus

Control methods, which are mostly practiced by local people, were tillage and hand weeding (63\%). Chemicals (45\%) also used to reduce the impact of parthenium from their field crop. However, these methods were not an efficient to control parthenium weed distribution; rather it is expanding from time to time since its invasions. Taye (2002) reporting on current management practices stated that the control of Parthenium is entirely based on cultural and labour intensive practices such as tillage, hand weeding, mowing, hoeing and slashing. Small-scale farmers prepare their land using repeated oxen ploughings and/ or hoeing. Because of Parthenium extended tap-root system deep into the soil, mature plants of Parthenium are difficult to uproot. Hence, ploughing aimed at the control of Parthenium should be done at its early period of growth.

\section{Impacts of $P$. hysterophorus}

The respondents interviewed and suggested that P. hysterophorus has a number of socioeconomic impacts that include effect on crop and livestock production, human health, soil fertility and biodiversity.

\section{Impact of parthenium on crop production}

Of the interviewed respondents, 93\% in high infestation category and $87 \%$ in medium 
infestation were aware of the impact of the weed on crop. They reported that after introduction of this noxious weed, yield of crops reduced (74\%). These finding also indicated that seeds $P$. hysterophorus change the normal flavor of food (69\%) when mix with it, suppress the growth of crops (69\%), and cause loss of soil fertility (42\%). This finding showed that the P. hysterophorus compete and suppress the growth due its allelopathic nature. The chemical also reduces the fertility of soil. This in line with Navie et al. (1996) and Evans (1997) who reported that the main impact of parthenium on crops relates to its allelopathic properties. The chemicals significantly inhibit the germination and subsequent growth of a range of crop plants.

Table 6. Respondents' perception on effects of P. hysterophorus on crop production in East Shewa and West Arsi Zones, Ethiopia.

\begin{tabular}{lcccccccc}
\hline Effect on crop production & $\begin{array}{c}\text { High } \\
\text { infestation } \\
\mathrm{N}=60\end{array}$ & \multicolumn{2}{c}{$\begin{array}{c}\text { Medium } \\
\text { infestation } \\
\mathrm{N}=60\end{array}$} & $\begin{array}{c}\text { No infestation } \\
\mathrm{N}=40\end{array}$ & \multicolumn{2}{c}{$\begin{array}{c}\text { Total } \\
\mathrm{N}=160\end{array}$} \\
\cline { 2 - 9 } & $\mathrm{n}$ & $\%$ & $\mathrm{n}$ & $\%$ & $\mathrm{n}$ & $\%$ & $\mathrm{n}$ & $\%$ \\
\hline Yield loss & 56 & 93 & 52 & 87 & 10 & 25 & 118 & 74 \\
Change normal flavor of food & 54 & 90 & 46 & 77 & 10 & 25 & 110 & 69 \\
Suppress crop growth & 50 & 83 & 41 & 68 & 20 & 50 & 111 & 69 \\
Loss of soil fertility & 46 & 77 & 19 & 32 & 2 & 5 & 67 & 42 \\
\hline
\end{tabular}

$\mathrm{N}=$ sample size of each category, $\mathrm{n}=$ Frequency

\section{Impact of parthenium on livestock production}

Impacts of $\mathrm{P}$. hysterophorus on animal productivity were recognized by many respondents. Its impact on grazing land was reported by $98 \%, 80 \%$ and $35 \%$ of the respondents in high, medium and noninfestation, respectively (Table 7). Large number of respondents incited that grass species are disappearing from the area furthermore their livestock endangered. This indicated that the weed colonized grazing fields, thus causing feed scarcity. This agrees with report of the J ayachandra (1971) who stated that the weed can be a serious problem in grasslands in and can reduce the pasture carrying capacity by up to $90 \%$.

Respondents in all categories also reported that the milk (53\%) and meat (46\%) of animals that graze on P. hysterophorus infested field is bitter and not palatable. Sixty three percent (63\%) of respondents also reported that animals feed on parthenium dominate grazing land lost weight and get diarrhea. In high infestation places P. hysterophorus could completely overlook grazing field, resulting in displacing grass species and animals forced to eat the weed especially during dry season.

Table 7. Respondents perception on effect of P. hysterophorus on livestock production in East Shewa and West Arsi Zones, Ethiopia.

\begin{tabular}{lcccccccc}
\hline Effect on life stock & $\begin{array}{c}\text { High infestation } \\
\mathrm{N}=60\end{array}$ & \multicolumn{2}{c}{$\begin{array}{c}\text { Medium } \\
\text { infestation } \\
\mathrm{N}=60\end{array}$} & $\begin{array}{c}\text { No infestation } \\
\mathrm{N}=40\end{array}$ & \multicolumn{2}{c}{$\begin{array}{c}\text { Total } \\
\mathrm{N}=160\end{array}$} \\
\cline { 2 - 9 } & $\mathrm{n}$ & $\%$ & $\mathrm{n}$ & $\%$ & $\mathrm{n}$ & $\%$ & $\mathrm{n}$ & $\%$ \\
\hline Grazingland & 59 & 98 & 48 & 80 & 14 & 35 & 121 & 76 \\
Animal Health & 52 & 87 & 40 & 67 & 8 & 20 & 100 & 63 \\
Milk Product & 39 & 65 & 39 & 65 & 7 & 18 & 85 & 53 \\
Meat product & 29 & 48 & 36 & 60 & 8 & 20 & 73 & 46 \\
\hline
\end{tabular}

$\mathrm{N}=$ sample size of each category, $\mathrm{n}=$ Frequency

\section{Impact of parthenium on human health}

P. hysterophorus has health hazards on human being, which include allergic, skin itching (irritation), cough and hemorrhage. $70 \%$ of respondents in high infestation category, 55\% in medium and $33 \%$ in non-infestation category grumble the effect of $\mathrm{P}$. hysterophorus on human health. Fifty eight percent of respondents in high infestation, 57\% in medium infestation category reported that P. hysterophorus cause allergy and dermatitis when contact with body (Table 8).
P. hysterophorus also causes cough and hemorrhage as reported by $38 \%$ and $23 \%$ of the respondents in the high infestation category and $15 \%$ of the respondents in the medium infestation categories, respectively (Table 8). Evans (1997) and Towers and Subba Rao (1992) also reported that close contact with P. hysterophorus could cause allergic contact dermatitis while inhalation of pollen can cause allergic rhinitis, which can develop into bronchitis or asthma in susceptible humans. 
Table 8. Respondents perception on effect of P. hysterophorus on human health in East Shewa and West Arsi Zones, ONRGS.

\begin{tabular}{lcccccccc}
\hline Effect on Human Health & \multicolumn{2}{c}{$\begin{array}{c}\text { High } \\
\text { infestation } \\
\text { N=60 }\end{array}$} & \multicolumn{2}{c}{$\begin{array}{c}\text { Medium } \\
\text { infestation } \\
\text { N=60 }\end{array}$} & \multicolumn{2}{c}{$\begin{array}{c}\text { No infestation } \\
\text { N=40 }\end{array}$} & \multicolumn{2}{c}{$\begin{array}{c}\text { Total } \\
\text { N=160 }\end{array}$} \\
\cline { 2 - 9 } & $\mathrm{n}$ & $\%$ & $\mathrm{n}$ & $\%$ & $\mathrm{n}$ & $\%$ & $\mathrm{n}$ & $\%$ \\
\hline Allergic and dermatitis & 35 & 58 & 34 & 57 & 1 & 3 & 70 & 44 \\
Skin itching & 26 & 43 & 11 & 18 & 5 & 13 & 42 & 26 \\
Cough & 23 & 38 & 9 & 15 & 0 & 0 & 32 & 20 \\
Bring hemorrhage & 14 & 23 & 9 & 15 & 0 & 0 & 23 & 14 \\
\hline
\end{tabular}

$\mathrm{N}=$ sample size of each category, $\mathrm{n}=$ Frequency

\section{Conclusions}

Parthenium hysterophorus belongs to the family Asteraceae, an extremely diverse family with a cosmopolitan distribution. It was regarded to be introduced in Ethiopia accidentally through aid shipments or from Somalia during Ethio-Somali war in 1976/77. Its invasion expanded at alarming rate in all directions mainly following slope gradient and main road. This investigation was initiated with the objectives to assess the community perception on means and source of introduction, dispersal, habitats and practices to control and to assess the socio-economic impacts of P. hysterophorus in study area. Semistructured questionnaires and focused group discussion were conducted with farmers, development agents (DAs), experts in the different levels of Minster of agriculture to collect data on the impact of parthenium. Most of respondents in the study area knew the impacts, source of introduction and means of dispersal of parthenium. In high infestation category, all respondents became aware about the weed. However, despite their awareness the rate of infestation increasing from time to time, this may be because of improper action was not done by different stake holders. This study indicated that $88 \%, 63 \%$ and $43 \%$ of respondents in high, medium and non-infestation category were perceived that parthenium was introduced by following vehicles road and rail ways. According to $95 \%$ of respondents in high infestation category and $85 \%$ in medium infestation, $\mathrm{P}$. hysterophorus grows through out of the year. Fifty five of respondents in non-infestation category also believed that the weed grows all time in the year. Many mechanisms were assumed by respondents for fast distribution P. hysterophorus in the study zones. These dispersal mechanisms include vehicles (65\%), wind (55\%), flood (46\%), livestock (45\%), seeds (41\%) and construction materials (28\%). According to the respondents in high infestation category roadside (98\%), pastoral (97\%), village (95\%), crop land (92\%) and waste land (67\%) were the highly infested habitats, while respondents in no infestation category observed parthenium on roadside (25\%), pastoral (25\%), village (24\%), crop land (25\%) and wasteland (20\%) in nearby districts. Control methods, which are mostly practiced by local people, were tillage and hand weeding (63\%). Chemicals (45\%) also used to reduce the impact of parthenium from their field crop. The respondents interviewed suggested that P. hysterophorus has a number of socioeconomic impacts that include effect on crop and livestock production, human health, Soil fertility and biodiversity.

\section{References}

Adane, K. 2008. Distribution of parthenium weed and some socio- and ecological impacts in the central rift Valley. M.Sc. Thesis presented to School of graduate studies Addis Ababa University, Ethiopia. 30 p.

Auld, B.A., Hosking, J . and McFadyen, R.E. 1983. Analysis of the spread of tiger-pear and parthenium weed in Australia. Australian Weeds. 2: 56-60.

Belachew, K. and Tessema, T. 2015. Assessment of Weed Flora Composition in Parthenium (Parthenium hysterophorus L.) Infested Area of East Shewa Zone, Ethiopia. Malaysian J. Med. Biol. Res. 2(1): 63-70.

Besufekad. T., Das, T. K., Mahadevappa, M., Taye, T. and Tamado, T. 2005. The Weed Parthenium: Its Distribution, Biology, Hazards and Control Measures. Pest Manag. J. Ethiopia. 9: 1-17.

Evans, H.C. 1997. Parthenium hysterophorus: A review of its weed status and the possibilities for biological control. Biocontrol News and Information. 18: 89-98.

GISP (Global Invasive Species Programme). 2004. Africa Invaded: The Growing Danger of Invasive Alien Species. Global invasive Species Programme, Cape Town. International Conference on Parthenium Management, 6 - 8 October 1997, University of Agricultural Sciences, Dahrwad, India, pp. 55-62.

Jayachandra, M. 1971. Parthenium weed in Mysore state and its control. Curr. Sci. 40: 568-569. 
Kifle, B., Taye, T. and Erine, W. 2011. Competitiveness of Parthenium hysterophorus with other plant species. Ethiopian J. Weed Manage. 4(1): 15-24.

Kololgi, P.D., Kololgi, S.D. and Kololgi, N.P. 1997. Dermatological hazards of parthenium in human beings. In: Mahadevappa, M. and Patil, V.C. (eds), Proceedings of the First International Conference on Parthenium Management, 6 - 8 October 1997, University of Agricultural Sciences, Dahrwad, India, 1819. from the lake Baringo area of Kenya. ICRAF working paper No. 3, World Agroforestry, Nairobi, Kenya.

Navie, S.C., McFadyen, R.E., Panetta, F.D. and Adkins, S.W. 1996. The biology of Australian Weeds 27: Parthenium hysterophorus L. Plant Prot. Quart. 11: 76 - 87.

Niguse, H., Taye, T. and Kifle, B. 2016. Distribution and Abundance of Parthenium (Parthenium hysterophorus L.) in East Shewa and West Arsi Zones of Ethiopia. J. Biol. Agric. Healthcare. 6(5): 65-71.

Parsons, W.T. and Cuthbertson, E.G. 1992. Noxious weeds of Australia. Inkata press, Melbourne, $692 \mathrm{p}$

Senayit, R., Agajie, T., Taye, T., Adefires, W. and Getu, E. 2004. Invasive Alien Plant Control and Prevention in Ethiopia. Pilot Surveys and Control Baseline Conditions. Report submitted to EARO, Ethiopia and CABI under the PDF B phase of the UNEP GEF Project - Removing Barriers to Invasive Plant Management in Africa. EARO, Addis Ababa, Ethiopia. 224 p.

Srirama Rao, P., Nagpal, S., Rao, B.S., Prakash O. and Rao, P.V. 1991. Immediate hypersensitivity to Parthenium hysterophorus. II. Clinical studies on the prevalence of Parthenium rhinitis. Clinical Exptl. Allergy. 21: 55-62.

Tamado, T., Ohlander, L. and Milberg, P. 2002. Interference by the weed Parthenium hysterophorus L. with grain sorghum: Influence of weed density and duration of competition. Int. J. Pest Manag. 48: 20-27.

Taye, T. 2002. Investigation of Pathogens for Biological Control of Parthenium (Parthenium hysterophorus L.) in Ethiopia. $\mathrm{PhD}$ Thesis. Humboldt- Universitat zu Berlin, Landwirtschaftlich-Gartnerischen Fakultat, Berlin. 152p.

Taye, T., Einhorn, G., Gossmann, M., Büttner, C. and Metz, R. 2004. The Potential of Parthenium Rust as Biological Control of Parthenium Weed in Ethiopia. Pest Manag. J. Ethiopia 8: 83-95.

Towers, G.H.N. and Subba Rao, P.V. 1992. Impact of the pan-tropical weed, Parthenium hysterophorus L. on human affairs. In: Richardson, R.G. (ed) Proceedings of the 1st International Weed Control Congress, Melbourne, Australia. Melbourne; Weed Science Society of Victoria, pp. 134- 138.

Wittenberg, R. 2004. Instruments and Tools for Assessing the Impact of Invasive Alien Plant Species in Africa. Report submitted under the PDF-B phase of the UNEP/GEF Project: Removing Barriers to Invasive Plant Management in Africa. $\mathrm{CAB}$ International Africa Regional Centre, Nairobi. $123 \mathrm{p}$. 